\title{
PENGARUH PENDEKATAN SAVI TERHADAP KEMAMPUAN KOMUNIKASI DAN PENALARAN MATEMATIKSERTA KEMANDIRIAN BELAJAR SISWA SMP
}

Oleh:

\author{
Haerudin \\ Guru SD Yakeswa Bandung \\ heruquantumsains@yahoo.co.id
}

\begin{abstract}
SAVI kepanjangan dari Somatis, Auditori, Visual, dan Intelektual merupakan sebuah pendekatan dalam pembelajaran yang diharapkan mampu memberikan kontribusi yang baik dalam upaya untuk meningkatkan kemampuan komunikasi dan penalaran matematik serta kemandirian belajar siswa SMP. Dalam pendekatan SAVI seluruh indera dipergunakan dalam belajar. Kemampuan mendengar, membaca, menyimak, merefleksi diri, mengatakan sesuatu, melakukan tindakan, dan mempergunakan intelektual merupakan bagian penting dari pendekatan SAVI. Dengan kemampuan tersebut, akan memudahkan siswa dalam mengkomunikasikan matematika, menggunakan daya nalarnya sehingga mudah difahami dan akhirnya akan menumbuhkan rasa kemandirin belajar yang tinggi.
\end{abstract}

Kata Kunci : Pendekatan SAVI, Komunikasi Matematis, Penalaran Matematis, Kemandirian Belajar.

SAVI stands for Somatic, Auditory, Visual, and Intellectual is an approach to learning that is expected to give a good contribution in an effort to improve communication skills and mathematical reasoning, the independence of junior high students. In all senses SAVI approach used in the study. Listening skills, reading, listening, reflection, say something, take action, and use the intellectual is an important part of the SAVI approach. With these capabilities, will allow students to communicate mathematics, using the power of reason that is easily understood and will ultimately foster a high sense of independent learning.

Key words : SAVI Approach, Mathematical Communication, Mathematical Reasoning, Learning Independence

\section{Latar Belakang Masalah}

Kemampuan komunikasi dan penalaran matematik merupakan bagian yang utama yang hendak dicapai dalam tujuan pembelajaran matematika. Hal ini sesuai dengan Permendiknas Nomor 20 tahun 2006 (Wijaya 2012: 16) tentang standar isi, disebutkan bahwa pembelajaran matematika bertujuan supaya siswa memiliki kemampuan sebagai berikut:

1. Memahami konsep matematika, menjelaskan keterkaitan antar konsep dan mengaplikasikan konsep atau algoritma, secara luwes, akurat, efisien, dan tepat, dalam pemecahan masalah. 
2. Menggunakan penalaran pada pola dan sifat, melakukan manipulasi matematika dalam membuat generalisasi, menyusun bukti, atau menjelaskan gagasan dan pernyataan matematika.

3. Memecahkan masalah yang meliputi kemampuan memahami masalah, merancang model matematika, menyelesaikan model dan menafsirkan solusi yag diperoleh.

4. Mengkomunikasikan gagasan dengan simbol, tabel, diagram, atau media lain untuk memperjelas keadaan atau masalah.

5. Memiliki sikapmenghargai kegunaan matematika dalam kehidupan, yaitu rasa ingin tahu, perhatian, dan minat dalam memplajari matematika, sera sikap ulet dan percaya diri dalam pemecahan masalah.

Selain itu kemampuan komunikasi dan penalaranmatematik merupakan aspek yang sangat penting dan esensial. Turmudi (2008: 55) mengatakan bahwa Aspek komunikasi dan penalaran hendaknya menjadi aspek penting dalam pembelajaran matematika. Penalaran matematika merupakan suatu kebiasaan otak yang apabila dikembangkan dengan baik dan konsisten akan memudahkan dalam mengkomunikasikan matematika baik secara tertulis maupun lisan. Menuangkan gagasan dan ide-ide matematika bukanlah hal yang mudah perlu kecermatan dan daya nalar yang baik. Begitu juga ketika menyelesaikan soal-soal matematika terutama bila ingin mendapatkan kesimpulan yang logis dari data dan sumber yang relevan.

Salah satu ciri dari matematika adalah penalaran deduktif, yaitu kebenaran suatu pernyataan atau konsep yang diperoleh sebagai akibat logis dari kebenaran yang sudah ada sebelumnya dimana nilai kebenaranya bersifat mutlak benar atau salah dan tidak keduanya bersama-sama. Sebagaimana yang diungkapkan Sumarmo (2012:20) yang mengatakan bahwa nilai kebenaran dalam penalaran deduktif bersifat mutlak atau salah dan tidak keduanya bersama-sama.

Menurut Turmudi (2008: 55) bahwa komunikasi adalah bagian yang esensial dari matematika dan pendidikan matematika. Bisa difahami bahwa tanpa adanya komunikasi yang baik sangat sulit bisa mengembangkan matematika sebagaimana tujuan pembelajaran yang telah ditetapkan. Hal ini karena proses komunikasi akan membantu siswa dalam membangun makna, menyampaikan gagasan dengan benar, dan memudahkan dalam menjelaskan gagasan-gagasan tersebut kepada orang lain sehingga informasinya mudah dimengerti dan difahami.

Pentingnya pemilikan kemampuan komunikasi matematik dijelaskan pula oleh Asikin (Sumarmo, 2012: 14) yaitu membantu siswa menajamkan cara siswa berpikir, sebagai alat untuk menilai pemahaman siswa, membantu siswa mengorganisasi pengetahuan matematika mereka, membantu siswa membangun pengetahuan matematikanya, meningkatkan kemampuan pemecahan masalah matematik, memajukan penalarannya, membangun kemampuan diri, meningkatkan 
keterampilan sosialnya, serta bermanfaat dalam mendidrikan komunitas matematik.Turmudi (2008: 55) menambahkan bahwa proses komunikasi membantu membangun makna dan kelengkapan gagasan dan membuat hal ini menjadi milik publik.

Baik kemampuan komunikasi dan penalaran matematik sangat berperan dalam membuat siswa mandiri dalam belajar. Dengan kemampuan tersebut diharapkan siswa akan semakin senang dalam belajar matematika, semakin terpacu mempelajarinya dan baik pola pikirnya, dan semakin tertantang dalam menyelesaikan soal-soal matematikanya. Dengan demikian, siswa akan lebih mandiri dalam belajar dan selalu berusaha agar dirinya mampu menguasai matematika dengan baik.

Kemandirian belajar sangat penting dimiliki oleh siswa. Siswa yang mandiri dalam belajar berarti siswa tersebut memiliki sikap dan prilaku, merasakan sesuatu, bernalar dan mengambil keputusan sesuai dengan kemampuannya sendiri. Berkenaan dengan prilaku mandiri, Monk, dkk (1999: 279) mengatakan bahwa orang yang mandiri akan memperlihatkan prilaku yang eksploratif, mampu mengambil keputusan, percaya diri dan kreatif. Selain itu, mampu bertindak kritis, tidak takut berbuat sesuatu, mempunyai kepuasan dalam melakukan aktifitasnya, percaya diri, dan mampu menerima realitas serta dapat memanipulasi lingkungan, mampu berinteraksi dengan teman sebaya, terarah pada tujuan dan mampu mengendalikan diri.

Namun kenyataan di lapangan untuk meningkatkan kemampuan penalaran dan komunikasi matematik serta kemandirian belajar tidaklah mudah. Hal ini karena sebagian besar guru masih mengajar dengan cara yang biasa sehingga prosespembelajaran masih terfokus pada guru dan kurangnya inovatif dalam pembelajaran. Menciptakan pembelajaran yang inovatif, bermutu, menyenangkan, dan pembelajaran yang terfokus pada siswa sesuai dengan tingkat kemampuan siswa sangat diperlukan.

Selain hal tersebut di atas, perlu adanya pandangan baru dalam matematika. Turmudi (2008: 6) berpendapat bahwa pergeseran cara pandang matematika akan berpengaruh terhadap cara penyampaian matematika kepada para siswa. Adanya pandangan bahwa matematika sebagai "strict body of knowledge" telah meletakkan pondasi bahwa siswa adalah objek pasif,karena yang diutamakan disini "knowledge of mathematics". Dalam kondisi seperti ini pula matematika dipandang sebagai hal yang statis sehingga pertumbuhan teori matematis sangatlah lamban.

Dalam belajar melibatkan aktivitas seluruh indera itu sangat penting dan berpengaruh dalam proses pembelajaran. Magnesen (dalam Dryden \& Jeannette, 2000: 100) mangatakan bahwa dalam belajar siswa 10\% akan menangkap pelajaran dari apa yang dibaca, 20\% dari apa yang didengar, 30\% dari apa yang dilihat, 50\% 
dari apa ang dilihat dan didengar, 70\% dari apa yang dikatakan, dan 90\% dari apa yang dilakukan dan dikatakan.

Salah satu pendekatan yang dapat digunakan untuk meningkatkan kemampuan komunikasi dan penalaran matematik serta kemandirian belajar siswa adalah pendekatan SAVI, karena pendekatan SAVI lebih berorientasi pada siswa yang menggabungkan gerak fisik dengan aktivitas intelektual dan melibatkan semua indera sehingga akan berpengaruh besar pada pembelajaran. SAVI kepanjangan dari Somatis, Auditori, Visual, dan Intelektual. Menurut Meier (2002: 91-92) bahwa unsur-unsur SAVI mudah diingat, Somatis: belajar dengan bergerak dan berbuat, Auditori: belajar degan berbicara dan mendengar,Visual: belajar dengan mengamati mengambarkan, dan Intelektual: belajar dengan memecahkan masalah dan merenung.

\section{Kajian Teori}

\section{Pendekatan SAVI}

Pendekatan SAVI adalah cara belajar yang disertai gerak fisik, berbicara, mendengarkan, melihat, mengamati, dan menggunakan kemampuan intelektual untuk berpikir, menggambarkan, menghubungkan, dan membuat kesimpulan dengan baik. Metode ini diharapkan mampu mengatasi masalah-masalah terutama berkenaan dengan proses berpikir kreatif matematis siswa.

Pendekatan SAVI bisa juga diartikan sebagai metode pembelajaran yang melibatkan seluruh anggota tubuh dari gerakan tubuh, pendengaran, kemampuan membayangkan, dan mampu bersifat cendikia atau berkait dengan kemampuan merenungkan, merumuskan, dan mengait-ngaitkan dengan memfungsikan pikiran secara baik dan benar.

Meier (2002: 91) berpendapat bahwa pembelajaran tidak otomatis meningkat dengan menyuruh orang berdiri dan bergerak kesana kemari. Akan tetapi, menggabungkan gerakan fisik dengan aktivitas intelektual dan pengunaan semua indera dapat berpengaruh besar pada pembelajaran. Saya namakan ini belajar SAVI. Unsur-unsurnya mudah diingat.

\section{Somatis : Belajar dengan bergerak dan berbuat.}

Belajar somatis berarti belajar dengan indera peraba, kinestetis, praktis melibatkan fisik dan menggunakannya serta menggerakan tubuh sewaktu belajar. Menurut penelitian neurologis, tubuh dan pikiran bukan merupakan dua entitas yang terpisah. Temuan mereka menunjukkan bahwa pikiran tersebar di seluruh tubuh. Maksudnya tubuh adalah pikiran dan pikiran adalah tubuh. Keduanya merupakan satu sistem 
elektris kimiawi-biologis yang benar-benar terpadu. Menghalangi fungsi tubuh dalam belajar berarti dapat menghalangi fungsi pikiran sepenuhnya. Oleh karena itu, untuk merangsang hubungan pikiran tubuh, harus diciptakan suasana belajar yang dapat membuat orang bangkit dan berdiri dari tempat duduk dan aktif secara fisik dari waktu ke waktu.

Beberapa langkah berikut dalam pembelajaran yang dapat digunakan untuk mengoptimalkan pembelajaran somatis adalah:

- Membuat model dalam suatu proses

- Secara fisik menggerakkan berbagai komponen dalam suatu proses atau sistem

- Menciptakan bagan, diagram, ata piktogram

- Memperagakan suatu proses, sistem, atau seperangkat konsep

- Melengkapi suatu proyek yang memerlukan kegiatan fisik

- Melaksanakan pelatihan belajar aktif seperti simulasi, permainan belajar dan lain-lain.

- Dalam tim, menciptaka pelatihan pembelajaran aktif bagi seluruh kelas.

Dalam pembelajaran maematike sendiri,langkah-langkah yang dapat ditempuh dalam mengoptimalkan aktivitas somatis antara lain:

- Membuat grafik suatu fungsi, membuat model bagun segitiga, mencari kreasi jaring-jaring kubus atau balok.

- Melengkapi tabel hasil pengamatan.

- Bergantian peran dalam kelompok belajar.

\section{Auditori : Belajar dengan berbicara dan mendengar.}

Belajar auditori berarti belajar dengan melibatkan kemampuan audotori (pendengaran). Ketika telingan menangkap dan menyimpan informasi auditori, beberapa area penting di otak menjadi aktif. Dalam merancang pembelajaran matematika yang menarik bagi saluran auditori (pendengaran), guru bisa melakukan tindakan seperti membicarakan materi apa yang sedang dipelajari. Siswa diharapkan mampu mengungkapkan pendapat atas informasi yang didengarkan atas penjelasan guru.

Aktivitas yang dapat dilakukan dalam aktivitas belajar Auditori dalam matematika antara lain:

- Membicarakan apa yang sedang dipelajari dan bagaimana menerapkannya.

- Memperagakan dan menjelaskan hasil diskusi.

- Mendengar materi yang disampaikan dan merangkumnya.

- Mengkomunikasikan ide-ide matematika dan memberikan penjelasanya. 


\section{Visual : Belajar dengan mengamati dan menggambarkan.}

Belajar visual adalah belajar dengan melibatkan kemampuan visual (penglihatan), dengan alasan bahwa di dalam otak terdapat lebih banyak perangkat memproses informasi visual daripada indera yang lain. Dalam merancang pembelajaran yang menarik bagi kemampuan visual, seoarng guru dapat melakukan tindakan seperti meminta siswa menerangkan kembali materi yang sudah diajarakan, menggambarkan proses, prinsip, atau makna yang dicontohkannya.

Aktivitas yang dapat dilakukan dalam aktivitas belajar visual dalam matematika antara lain:

- Mengamatai grafik atau diagram.

- Melihat benda dimensi tiga secara langsung.

- Memvisualisasikan hasil kerja kelompok dalam bentuk gambag atau grafik.

\section{Intelektual : Belajar dengan memecahkan masalah dan merenung.}

Belajar intelektual berarti menunjukkan apa yang dilakukan siswa dalam pikiran mereka secara internal ketika mereka menggunakan kecerdasan untuk merenungkan suatu pengalaman dan menciptakan hubungan makna, rencana, dan nilai dari pangalaman tersebut. Belajar intelektual adalah bagian untuk merenung, mencipta, memecahkan masalah dan membangun makna. dalam membangun proses belajar intelektual, siswa diminta mengerjakan soal-soal dari materi yang sudah diajarkan dan dijelaskan oleh guru. Meier (2002: 99) menambahkan bahwa intelektual adalah pencipta makna dalam pikiran; sarana yang digunakan manusia untuk "berpikir", menyatukan pengalaman, menciptakan jaringan saraf baru, dan belajar.

Beberapa cara yang dapat ditempuh untuk mengoptimalkan aktivitas belajar intelektual dalam belajar matematika antara lain:

- Memecahkan masalah matematika.

- Menganalisis pengalaman, kasus atau hasil diskusi.

- Menciptakan makna pribadi.

- Meramalkan implikasi suatu gagasan.

Keempat unsur SAVI yaitu Somatis, Auditori, Visual, dan Intelektual harus disatukan dan dipadukan agar memberikan pengaruh yang besar bagi peningkatan kemampuan berpikir kreatif matematis siswa SMP.

\section{Kemampuan Komunikasi Matematik}

Kemampuan komunikasi sangat diperlukan dalam proses pembelajaran karena dengan komunikasi akan terjadi interaksi timbal balik dan terjadinya transfer informasi. Kemampuan komunikasi yang baik akan memungkinkan siswa aktif 
dalam proses pembelajaran dan memudahkannya dalam memberikan penalaran terhadap informasi tersebut.

Komunikasi adalah suatu proses penyampaian informasi atau pesan kepada orang lain dan sebaliknya sehingga apa yang diungkapkan tersebut dapat dipahami dan dimengerti dengan baik. Menurut TIM (Elida, 2012: 180) menyatakan bahwa komunikasi adalah pengiriman dan penerimaan pesan antara dua orang atau lebih sehingga pesan yang dimaksud dapat dipahami. Sedangkan Abdulhak (Elida, 2012: 180) berpendapat bahwa komnikasi dimaknai sebagai proses penyampaian pesan dari pengirim pesan kepada penerima pesan melalui saluran tertentu untuk tjuan tertentu.

Untuk menyampaikan gagasan matematika agar dapat diterima diperlukan adanya komunikasi yang dapat memberikan siswa memiliki kesempatan dan dorongan untuk mendengar dan berbicara (Auditori), menyimak (Visual), menggunakan penalarannya (Intelektual), dan akhir dapat diaktualisasikan melalui presentasi (Somatis) dengan penuh percaya diri (Kemandirian).

Kemampuan matematik adalah kemampuan menjelaskan idea matematik dengan gambar atau grafik, menghubungkan gambar, grafik atau situasi ke dalam idea matematika, dan menjelaskan serta membuat pertanyaan tentang matematika. Hal ini sesuai dengan apa yang disampaikan Eliot dan Kenney, Eds (Sumarmo, 2013: 35) bahwa kemampuan komunikasi matematika antara lain meliputi proses-proses matematika berikut:

1. Menyatakan suatu situasi atau masalah matematik atau kehidupan seharihari ke dalam bentuk gambar, diagram, bahasa atau simbol matematik, atau model matematik.

2. Menjelaskan suatu idea matematik dengan gambar, ekspresi, atau bahasa sendiri secara lisan atau tulisan.

3. Membuat suat cerita bedasarkan gambar, diagram, atau model matematik yang diberikan.

4. Menyusun pertanyaan tentang konten matematik yang diberikan.

Sedangkan NCTM (Wijaya, 2012: 72) merumuskan standar komunikasi (communicatioan Standard) untuk menjamin kegiatan pembelajaran matematika yang mampu mengembangkan kemampuan siswa dalam:

1. Menyusun dan memadukan pemikiran matematika melalui komunikasi.

2. Mengkomunikasikan pemikiran matematika secara logis dan sitematis kepada semua siswa, kepada guru, maupun orang lain.

3. Menganalisis dan mengevaluasi perkiran dan strategis matematis orang lain.

4. Menggunakan bahasa matematika untuk megekspresikan ide matematika secara tepat. 


\section{Kemampuan Penalaran Matematik}

Penalaran adalah proses atau aktivitas berfikir dalam menarik kesimpulan atau membuat pernyataan baru yang benar berdasarkan pada pernyataan yang telah dibuktikan kebenaranya. Keraf (Sumarmo, 2012: 16) mendefiisikan istilah penalaran serupa dengan penalaran proporsional atau penalaran logis dalam tes. Sedangkan Lengeot (Sumarmo, 2012: 16) berpendapat bahwa penalaran sebagai proses berpikir yang memuat kegiatan menarik kesimpulan berdasarkan data dan peristiwa yang ada. Hal senada juga diungkapkan Shurter dan Pierce (Sumarmo, 2012: 16) yang telah mendefinisikan penalaran sebagai proses memperoleh kesimpulan logis berdasarkan data dan sumber yang relevan. Sumarmo (2013 148) menegaskan pula bahwa penalaran merupakan proses berpikir dalam proses penarikan kesimpulan.

Secara garis besar terdapat dua jenis penalaran yaitu penalaran induktif yang juga dikenal dengan induksidan penalaran deduktif yang juga bisa disebut deduksi. Sumarmo (2013: 148) mengatakan bahwa penarikan kesimpulan yang berdasarkan sejumlah kasus atau contoh terbatas disebut induksi. Sedangkan penarikan kesimpulan berdasarkan aturan yang disepakati dinamakan deduksi.

Sumarmo (2013: 148) menjelaskan pula bahwa penalaran induktif adalah penalaran yang berdasarkan contoh-contoh terbatas yang teramati. Beberapa penalaran induktif diantaranya: penalaran analogi, generalisasi, estimasi atau memperkirakan jawaban dan proses solusi, dan enysun konjektur. Penalaran induktif di atas dapat digolongkan pada berpikir matematik tingkat rendah atau tingkat tinggi tergantung pada kekomplekan situasi yang terlibat.

Sedangkan penalaran deduktif adalah penalaran yang didasarkan pada aturan yang disepakati. Beberapa penalaran yang tergolong deduktif diantaranya: melakukan operasi hitung, menarik kesimpulan logis, memberi penjelasan terhadap model, fakta, sifat, hbungan atau pola, mengajukan lawan contoh, mengikuti aturan inferensi, memeriksa validitas argumen, membuktikan, dan menyusun argumen yang valid, merumuskan definisi dan menyusun pembuktian langsung, pembuktian tak lansung dan pembuktian dengan induksi matematika.

Penalaran induktif melibatkan persepsi tentang keteraturan.Dalam matematika, mendapatkan kesamaan tersebut dapat menjadi dasar dalam rangka pembentukan konsep, yaitu dengan cara mengurangi hal-hal yang harus diingat. Proses tersebut dinamakan abstraksi konsep.

Penalaran induktif memainkan peran penting dalam pengembangan dan penerapan matematika. Sebagai fakta, penemuan matematika ada pula yang berawal dari suatu penarikan kesimpulan dengan menerapkan panalaran induktif. Kesimpulan yang ditarik secara induktif tidak selalu dapat dibuktikan secara deduktif. Kesimpulan 
demikian dinamakan suatu konjektur. Konjektur adalah suatu tebakan, penyimpulan, teori, atau dugaan yang didasarkan pada fakta yang tak tertentu atau tak lengkap.

Kesimpulan umum yang ditarik dari jenis induktif generalisasi dapat merupakan suatu aturan, namun dapat pula sebagai prediksi yang didasarkan pada aturan itu. Penalaran induktif yang menunjukkan kegiatan menebak suatu aturan dapat dilakukan dengan menggunakan mesin fungsi sebagai proses kerja dalam menarik suatu kesimpulan.

\section{Kemandirian Belajar}

Kemandirian belajar adalah bagian yang tak terpisahkan dari tujuan pembelajaran matematika. Selain siswa mampu menggunakan penalaran dan mengkomunikasikan matematika dengan baik, kemandirian belajarnya dapat terus terbina. Siswa yang kemandirian belajarnya baik dan stabil maka dia akan mampu untuk menata dirinya dalam belajar, bersikap, bertingkah laku, dan mengambil keputusan yang sesuai dengan kehendaknya sendiri.Sebagaimana yang dikemukakan oleh Steinberg (dikutip Fleming, 2005, h.2), bahwa kemandirian didefinisikan sebagai kemampuan individu dalam bertingkah laku, merasakan sesuatu, dan mengambil keputusan berdasar kehendaknya sendiri.

Kemandirianbelajar identik dengan belajar mandiri. Kemandirian belajar bukan berarti belajar sendiri. Seringkali orang menyalahartikan kemandirian belajar sebagai belajar sendiri, padahal kemandirian belajar mempunyai makna yang cukup luas. Bandura (Sumarmo, 2013: 109) menyatakan bahwa kemandirian belajar diartikan sebagai kemampuan memantau prilau sendiri, dan merupakan kerja keras personaliti manusia dan menyarankan tiga langkah dalam melaksanakan kemandirian belajar yaitu (1) Mengamati dan mengawasi diri sendiri; (2) Membandingkan posisi diri dengan standar tertentu; (3) Memberikan respon sendiri baik terhadap respon,positif maupun negatif.Metode pengajaran berdasarkan pada prinsip kemandirian akan menjadikan siswa menjadi individu yang mandiri. Kemandirian yang dimiliki oleh siswa diwujudkan melalui kemampuannya dalam mengambil keputusan sendiri tanpa pengaruh dari orang lain. Kemandirian juga terlihat dari berkurangnya ketergantungan siswa terhadap guru di sekolah seperti, pada jam pelajaran kosong karena ketidakhadiran guru di kelas, siswa dapat belajar secara mandiri dengan membaca buku atau mengerjakan latihan soal yang dimiliki. Siswa yang mandiri, tidak lagi membutuhkan perintah dari guru atau orang tua untuk belajar ketika berada di sekolah maupun di rumah. Siswa yang mandiri telah memiliki nilainilai yang dianutnya sendiri dan menganggap bahwa belajar bukanlah sesuatu yang memberatkan, namun merupakan sesuatu yang telah menjadi kebutuhan bagi siswa untuk meningkatkan prestasi di sekolah. 
Kemandirian belajar merupakan kemampuan siswa dalam merancang belajarnya sendiri, mampu memantau, mengevaluasi, dan mereflesikan kegiatan belajarnya.

\section{Pembahasan}

Berdasarkan uraian di atas, jelas bahwa antara kemampuan penalaran, komunikasi, dan kemandirian belajar saling keterkaitan satu sama lain. Seorang siswa yang memiliki kemampuan penalaran matematiknya baik akan lebih mudah dalam mengembangkan kemampuan komunikasi matematiknya. Kebiasaan dalam menggunakan kemampuan penalaran dan komunikasi matematik akan berpengaruh pada perubahan sikap dan kebiasaan. Perubahan sikap yang diharapkan adalah meningkatnya kemandirian belajarnya.

Pendekatan SAVI memberikan peluang lebih besar bagi siswa dalam mengembangkan kemampuan penalaran dan komunikasi matematiknya. Seluruh alat indera dilibatkan dalam proses pembelajaran. Unsur somatisnya dikembangkan agar memiliki sikap kreatif dan berjiwa berani mengemukakan pendapatnya. Auditorinya juga diarahkan agar siswa memiliki kemampuan dalam berbicara dan teliti dalam mendengarkan setiap apa yang diungkapkan orang lain. Visualisasinya diarahkan memiliki pengamatan yang baik sehingga mampu memberikan tanggapan yang terarah dan sesuai dengan apa yang diharapkan. Akhirnya unsur intelektual dikembangkan agar siswa mampu berpikir dengan baik, kreatif, dan menyelesaikan permasalahan dengan baik.

Bila pendekatan SAVI dilaksanakan dengan baik maka bukan hanya kemampuan penalaran dan komunikasi matematiknya yang meningkat, akan tetapi kemandirian belajar juga akan meningkat. Akhirnya apa yang menjadi tujan dalam pembelajaran akan tercapai dengan baik.

\section{Kesimpulan}

Berdasarkan Latar Belakang Masalah dan Kajian Teori di atas, maka Pendekatan SAVI diasumsikan berpengaruh terhadap peningkatan kemampuan penalaran dan komunikasi matematik serta kemandirian belajar siswa. Tentunya bila pendekatan SAVI dilaksanakan dengan baik dan benar. 


\section{DAFTAR PUSTAKA}

Elida, N. (2012). Meningkatkan Kemampuan Komunikasi Matematik Siswa Sekolah Menengah Pertama Melalui Pembelajaran Think-Talk-Write (TTW). Jurnal Infinity. Vol. 1 No. 2 (178-185)

Fleming, M. (2005). Adolescent Autonomy: Desire, Achievement and DisobeyingParents between Early and Late Adolescence. Australian Journal of Education and Developmental Psychology. Vol.5. 116

Monks, F.J., dkk. (1999). Psikologi Perkembangan Pengantar dalam Berbagai Bagiannya. Yogyakarta: Gadjah Mada University.

Meier, D. (2002). The Accelerated Learning. Panduan Kreatif \& Efektif Meracang Program Pendidikan dan Pelatihan. Bandung: KAIFA

Dryden \& Jeannete, (2000). The Learning Revolution. Revolusi Cara Belajar. Bandung: KAIFA.

Sumarmo, (2012). Bahan Belajar Matakuliah Proses Berpikir Matematik Program S2 Pendidikan Matematika STKIP Siliwangi Bandung 2012. Bandung: STKIP Siliwangi. Untuk kalangan sendiri.

, (2013). Kumpulan Makalah Berpikir dan Disposisi Matematik serta Pembelajarannya. Pembelajaran Mateatika Untuk Mendukung Pelaksanaan Kurikulum Berbasis Kompetensi. Bandung: UPI. Untuk kalangan sendiri.

(2013). Kumpulan Makalah Berpikir dan Disposisi Matematik serta Pembelajarannya. Kemandirian Belajar: Apa, Mengapa, dan Bagaimana Dikembangkan pada Peserta Didik. Bandung: UPI. Untuk kalangan sendiri.

Turmudi, (2008). Landasan Filsafat dan Teori Pembelajaran Matematika (Berparadigma Eksploratif dan Ivestigatif). Jakarta: LEUSER CITA PUSTAKA.

Wijaya, A. (2012). Pendidikan Matematika Realistik. Suatu Pendekatan Pembelajaran Matematika. Yogyakara: GRAHA ILMU 